\title{
ADSORPTION OF NPK FERTILISER AND HUMIC ACID ON PALM KERNEL SHELL BIOCHAR
}

\author{
UTTRAN, A*; LOH, S K*; KONG, S H $^{\star *}$ and BACHMANN, R T
}

\begin{abstract}
To date, no study has been reported on adsorption capacity $\left(Q_{e}\right)$ of palm kernel shell (PKS) biochar for plant nutrients $\mathrm{NO}_{3}{ }^{-}, \mathrm{NH}_{4}{ }^{+}, \mathrm{PO}_{4}{ }^{3-}$ and $\mathrm{K}^{+}(\mathrm{NPK})$ while most biochar adsorption investigations have not considered the effect of dissolved soil organic matter e.g. humic acid (HA). In our study, we produced PKS biochar at different temperatures and holding times and conducted sorption experiments with a commercial NPK fertiliser and HA. HA-coated PKS biochar was investigated for its capability in adsorbing NPK. Equilibrium adsorption experiments showed that $\mathrm{NH}_{4}{ }^{+}$and $\mathrm{HA}$ were adsorbed with no effect for $\mathrm{NO}_{3}{ }_{3}^{-}$and $\mathrm{PO}_{4}{ }^{3-}$, while $\mathrm{K}^{+}$concentration in solution increased exponentially over time. The highest $\mathrm{Q}_{e}$ of $\mathrm{NH}_{4}{ }^{+}(0.522$ $\left.\pm 0.036 \mathrm{mg} \mathrm{g}^{-1} ; p<0.05\right)$ and that of $\mathrm{HA}\left(0.649 \pm 0.073 \mathrm{mg} \mathrm{g}^{-1}\right)$ were observed for $400^{\circ} \mathrm{C} P K S$ biochar. The best-fitted HA sorption with Freundlich isotherm $\left(R^{2}=0.904\right)$ reveals a heterogeneous surface and arguably multiple layer sorption of $\mathrm{HA}$. A 55.9\% reduction in $\mathrm{Q}_{e}$ of $\mathrm{NH}_{4}{ }_{4}^{+}$for $\mathrm{HA}$-coated $600^{\circ} \mathrm{C} P K S$ biochar suggests that performances observed in the laboratory cannot be directly extrapolated to the field. Furthermore, a realistic mechanistic understanding of PKS biochar sorption efficiency on NPK associated with soil matrix components such as humic substances, microorganisms and colloidal clay particles is essential.
\end{abstract}

Keywords: oil palm biomass, biochar, pyrolysis, nutrient adsorption, soil conditioner.

Date received: 17 October 2017; Sent for revision: 19 October 2017; Received in final form: 18 January 2018; Accepted: 3 May 2018.

\section{INTRODUCTION}

Char is a carbon-rich product obtained when biomass such as wood (chips, sawdust), crop/ forestry residues (leaves, barks) and oil palm byproducts [empty fruit bunch (EFB), palm kernel shell (PKS), oil palm frond] is heated in a closed

Malaysian Palm Oil Board, 6 Persiaran Institusi Bandar Baru Bangi, 43000 Kajang, Selangor, Malaysia. E-mail: lohsk@mpob.gov.my

** School of Foundation Studies, University College of Technology Sarawak, 96000 Sibu, Sarawak, Malaysia.

‡ Universiti Kuala Lumpur, Malaysian Institute of Chemical and Bioengineering Technology (MICET), Lot 1988, Kawasan Perindustrian, Bandar Baru Vendor, Taboh Naning, 78000 Alor Gajah, Melaka, Malaysia. container with little or no available air. The term 'biochar' is given to carbonised biomass if applied to soil in order to improve properties such as cation exchange capacity (CEC) (Cheng et al., 2008), pH (Topoliantz et al., 2005), plant-microbe interactions (Steiner et al., 2008) and water field capacity (Dugan et al., 2010). Biochar can also act as a carbon sink thus potentially mitigating the global warming effect (Woolf et al., 2010). For example, if all the unused PKS in Malaysia from the palm oil milling process amounting to 3.46 million tonnes (wet basis with $15 \mathrm{wt} . \%$ moisture) based on the generation rate of $0.20 \mathrm{t} \mathrm{t}^{-1}$ crude palm oil (Vijaya et al., 2008) would be converted to biochar with a yield of $33 \mathrm{wt} \%$ and an average carbon content of $69 \mathrm{wt} \%$ (Haryati et al., unpublished data), an estimated $\sim 2.46$ million tonnes $\mathrm{CO}_{2}$ could theoretically be locked away 
every year for at least 1000 years (Spokas, 2010). This would positively impact the carbon footprint of palm oil production in Malaysia.

Sorption-relevant physico-chemical properties of biochar are influenced by the feedstock composition (cellulose, hemicelluloses and lignin) and process conditions. As the temperature in biochar processing increases, the surface area of the biochar increases up to a certain temperature for a given holding time (Rafiq et al., 2016), but functional groups that provide cation and anion exchange capacity and $\mathrm{H} / \mathrm{C}$ ratio decrease (Guo and Rockstraw, 2007; Kloss et al., 2012). As a result, the biochar becomes more stable compared to the initial feedstock (Krull et al., 2009) but the sorption mechanism and biochar's nutrients adsorption capacity $\left(Q_{e}\right)$ may be affected.

Nutrient availability in the soil is crucial for plant growth. Factors such as vegetation and fertilisation, soil structure and texture, rainfall patterns, soil and soil solution chemistry, soil biology and nutrient cycles influence the soil nutrient availability. Typically, the ability of soil to retain ions in an exchangeable and plant-available form increases with soil organic matter (SOM) concentration, and this holds for biochar as well. For example, more than 600 years old biochar in Anthrosols from the Brazilian Amazon was found to have a greater ability to adsorb cations per unit carbon than other SOM due to its greater surface area, negative charge and charge density (Sombroek et al., 2003; Liang et al., 2006). Even addition of freshly produced charcoal from woody biomass into xanthic Anthrosol and fimic Ferralsol soil was reported to increase the nutrient availability except for $\mathrm{N}$ while nutrient leaching was comparatively low (Lehmann et al., 2003).

Biochar provides long-term benefits including greater stability of SOM and better retention of all cations due to a greater CEC (Lehmann et al., 2006). The CEC of chemically activated carbon from Metroxylon sagu increased from 143 to $192 \mathrm{cmol} \mathrm{kg}^{-1}$ leading to $50 \%$ increase in exchangeable $\mathrm{NH}_{4}{ }^{+}$which in turn improved the $\mathrm{NH}_{4}{ }^{+}$and $\mathrm{NO}_{3}^{-}$retention in soil compared with unsupplemented soil (Bernard et al., 2011). Most sorption studies reported biomassspecific sorption capacities for $\mathrm{NH}_{4}{ }^{+}$in the range of 0.1 to $3 \mathrm{mg} \mathrm{g}^{-1}$ that appeared to decrease with increasing pyrolysis temperature, while sorption of $\mathrm{PO}_{4}{ }^{3-}$ was mainly insignificant (Table 1 ). The $\mathrm{NO}_{3}$ adsorption was also reported in some cases and appeared to increase with increasing temperature (Table 1). The adsorption mechanisms of ammonia, the gaseous form of ammonium, onto plain biochar was reviewed by Spokas et al. (2011) who concluded that sorption and reaction potential of biochar with certain $\mathrm{N}$ compounds can be observed at ambient condition and found to depend on the presence of surface oxygen groups.
Interestingly, Chen and $\mathrm{Wu}$ (2004) reported a $34.7 \%$ reduction in specific surface area of H-type granular activated carbon coated with 4-8 $\mathrm{mg}$ humic acid (HA) per g carbon, while Martin et al. (2012) found that the $Q_{e}$ of herbicides diuron and atrazine on aged biochar in soil was reduced by $47 \%$ and $68 \%$, respectively. No study has yet looked into coating biochar with HA and assessing its performance in holding fertiliser nutrients. In this study, biochar derived from PKS was chosen since it is produced in significant amounts as a by-product during palm oil milling (Kong et al., 2014). Its sorption ability on plant nutrients $\mathrm{NO}_{3}{ }^{-}$, $\mathrm{NH}_{4}{ }^{+}, \mathrm{PO}_{4}{ }^{3-}$ and $\mathrm{K}^{+}$(NPK) including the associated effect in the presence of dissolved SOM, e.g. HA is so far not reported. Studies are available in which the significance of HA on fertiliser nutrient use efficiency was investigated in the absence of biochar. For example, Ahmad et al. (2012) applied a complete fertiliser formulation consisting of urea, triple phosphate and monophosphate amended with or without HA, fluvic acid, acidified HA and fluvic acid and humin to a Typic Paleudults soil to establish the urea-HA-P fertiliser efficiency in ammonia retention. The results showed that under field conditions HA does not have an effect on urea hydrolysis. The dry matter of the test crop increased with significant retention of soil exchangeable $\mathrm{NH}_{4}{ }^{+}$. Taufik et al. (2011) also observed similar results showing much reduced $\mathrm{NH}_{3}$ loss when acid-sulphate-urea-HA and ureaHA mixtures were applied in Typic Paleudults; thus improving urea and $\mathrm{N}$ use efficiency as well as reducing environmental pollution. Kasim et al. (2009) showed that addition of HA to soil with urea reduced $\mathrm{NH}_{3}$ loss and increased exchangeable $\mathrm{NH}_{4}{ }^{+}$arguably due to the high CEC of HA (417- 583

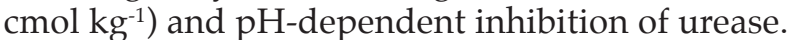

Therefore, the objectives of this study are to investigate the sorption of NPK ions as well as HA onto PKS biochar produced at different temperatures and holding times, and establish in a second set of experiments the effect of HA-coated PKS biochar on NPK sorption.

\section{MATERIALS AND METHODS}

\section{Materials}

The PKS was collected from MPOB Experimental Palm Oil Mill Technology Centre (POMTEC) in Labu, Negeri Sembilan, Malaysia. It was air-dried for three days before conversion into biochar. Reagents NitraVer5, PhosVer3, potassium 1, 2 and 3 , ammonium salicylate and ammonium cyanurate were obtained from $\mathrm{HACH}$. Compound fertiliser $\left(\mathrm{N}: \mathrm{P}_{2} \mathrm{O}_{5}: \mathrm{K}_{2} \mathrm{O}: \mathrm{MgO}=15: 15: 6: 4\right) \quad(\mathrm{NPKMg})$ was supplied by Chemical Company of Malaysia Berhad 


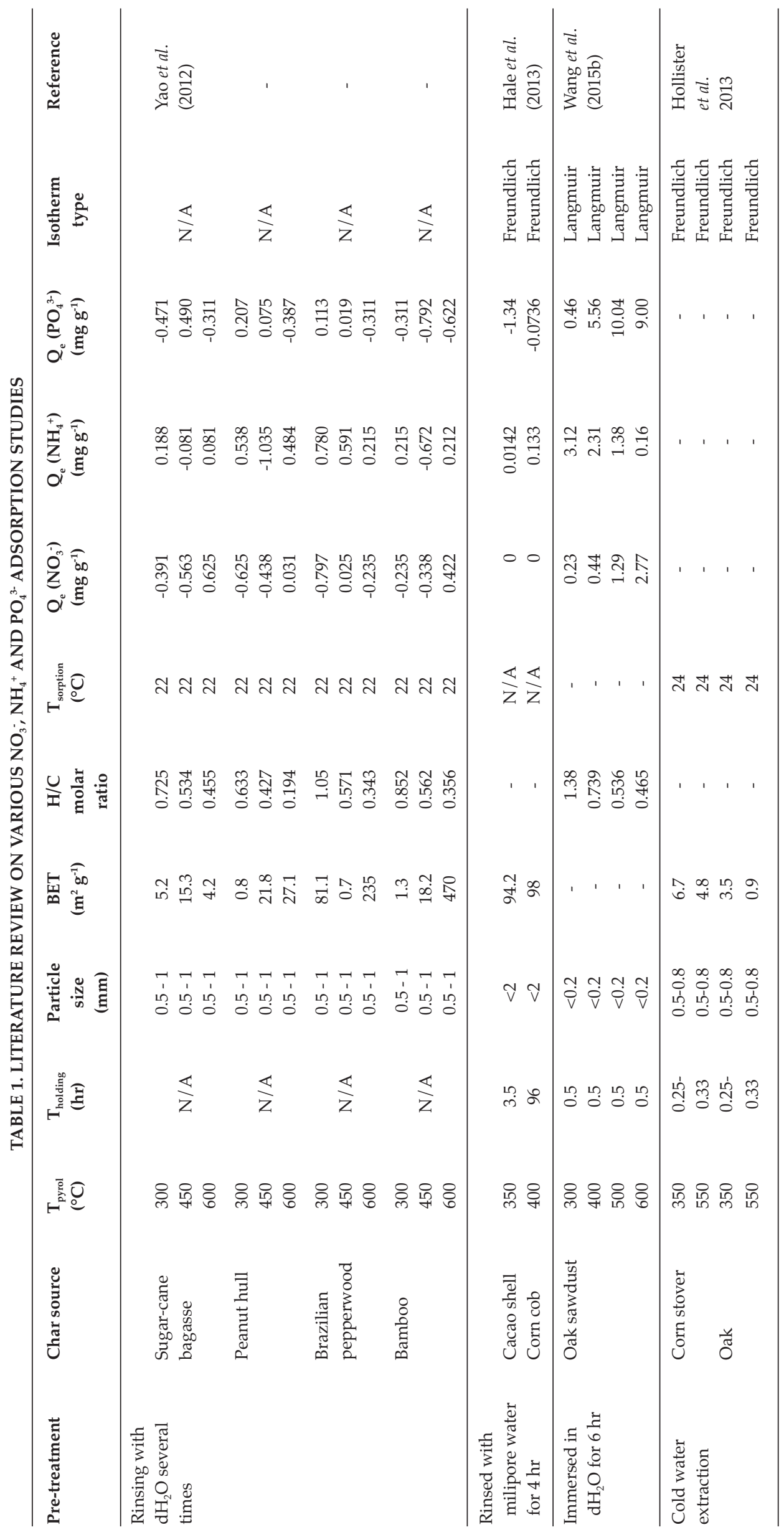




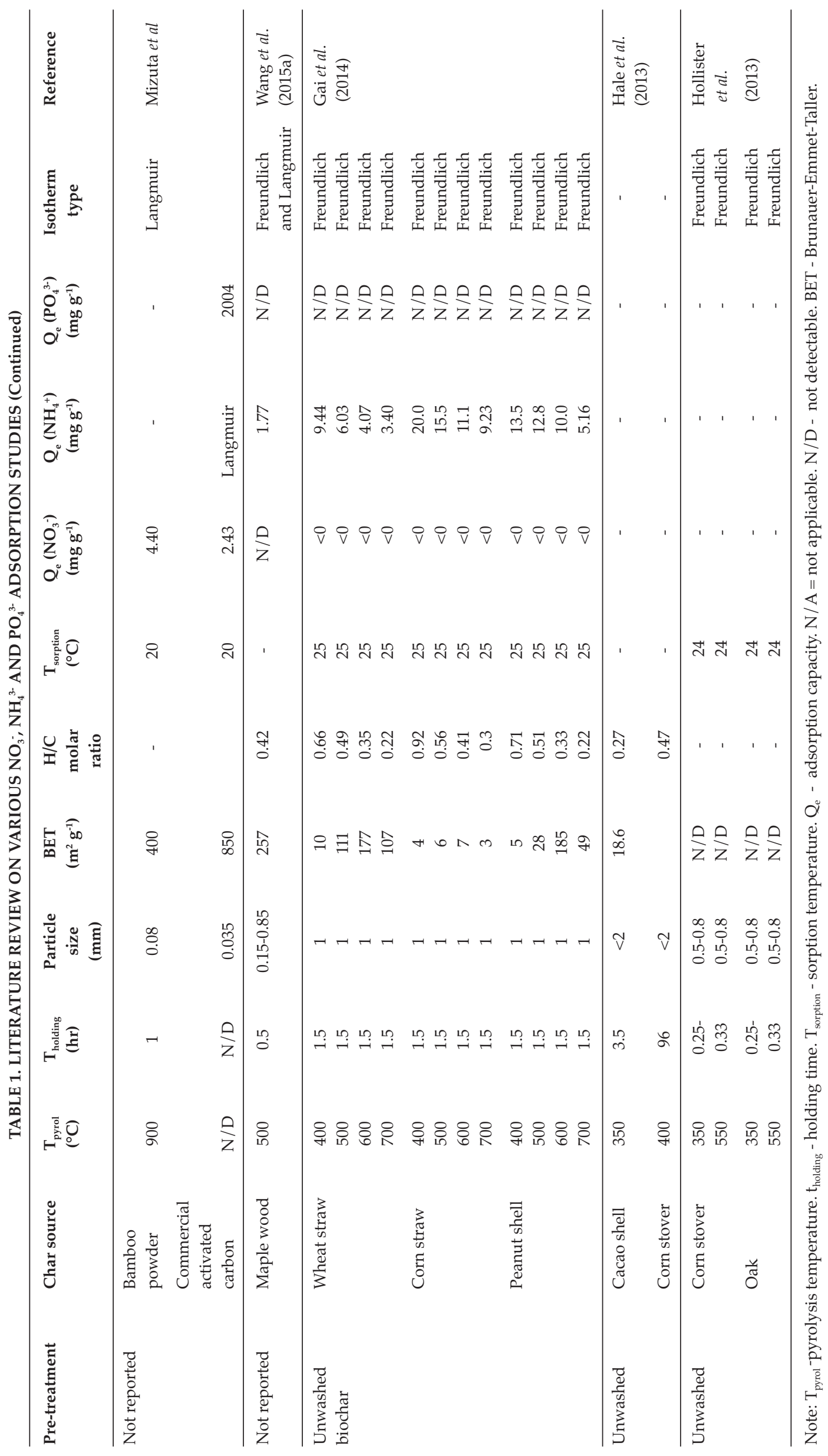


(CCM) while HA (technical grade) was purchased from Sigma Aldrich.

\section{PKS Biochar Production}

The biochar was produced from air-dried PKS (approximately $20 \mathrm{~kg}$ ) using the Biochar Experimenter's Kit (BEK) (All Powers Lab, USA) under allothermal conditions. Three batches of PKS biochars were produced separately at $400^{\circ} \mathrm{C}, 500^{\circ} \mathrm{C}$ and $600^{\circ} \mathrm{C}$, each with $1 \mathrm{hr}$ holding time and another two batches at $500^{\circ} \mathrm{C}$ for 0.5 and $1.5 \mathrm{hr}$ holding times, respectively (Kong et al., 2016). The PKS biochars were crushed using pestle and mortar, sieved to the desired particle size $(1-2.5 \mathrm{~mm})$, then stored in air tight amber plastic containers and labelled accordingly for adsorption study.

\section{Biochar Sample Preparation for Adsorption Study}

An approximate $90 \mathrm{~g}$ of PKS biochars were added to $250 \mathrm{ml}$ of deionised water $\left(\mathrm{dH}_{2} \mathrm{O}\right)$ and shaken at $170 \mathrm{rpm}$ on an orbital shaker until the conductivity of the solution reached equilibrium. The solution was replaced with fresh $\mathrm{dH}_{2} \mathrm{O}$, and the same procedure was applied until no further noticeable increase in conductivity. The washed biochars were filtered and dried in an oven at 103 $\pm 2{ }^{\circ} \mathrm{C}$ until constant weight. The final reading of the conductivity for the samples was converted into total dissolved solid (TDS) according to Day and Nightingale (1984) to estimate the amount of minerals leachable from the biochars.

\section{PKS Biochar Adsorption on Fertiliser Nutrients (NPKMg)}

Adsorption of nutrients on PKS biochar in aqueous solution containing $50 \mathrm{mg}$ litre $^{-1}$ of NPKMg fertiliser was studied. A fertiliser stock solution of $100 \mathrm{mg}$ litre $^{-1}$ was prepared by dissolving $0.1 \mathrm{~g}$ of oven-dried crushed NPKMg fertiliser into a litre of $\mathrm{dH}_{2} \mathrm{O}$. The solution was mixed for $1 \mathrm{hr}$, filtered using Whatman filter paper No. 5 and stored in a volumetric flask. A pre-weighed amount of $0.4 \mathrm{~g}$ of PKS biochar was added into $50 \mathrm{ml}$ of $\mathrm{dH}_{2} \mathrm{O}$ using a 250-ml Erlenmeyer flask and shaken at $170 \mathrm{rpm}$ for $2 \mathrm{hr}$ to remove any air bubbles trapped in the biochar pores. Fifty $\mathrm{ml}$ of the prepared fertiliser stock solution was then added. Aliquot samples were taken at various intervals and analysed for $\mathrm{NO}_{3}^{-}$(cadmium reduction method, $\mathrm{HACH}$ ), $\mathrm{N}_{4}^{+}$(salicylate method, $\mathrm{HACH}$ ), $\mathrm{PO}_{4}^{3-}$ (ascorbic acid method, $\mathrm{HACH}$ ) and $\mathrm{K}^{+}$(tetraphenlyborate method, HACH) using a BioRad i-Mark microtitre plate reader. Briefly, $0.0252 \mathrm{~g}$ of NitraVer5 reagent was added to $5 \mathrm{ml}$ of the sample in a Bijou bottle, shaken for $1 \mathrm{~min}$ and incubated for $5 \mathrm{~min}$. Next, $300 \mu \mathrm{l}$ of the solution was transferred into a 96-well polystyrene microtitre plate (MTP) and the $\mathrm{NO}_{3}$ absorbance measured at $500 \mathrm{~nm}$. For $\mathrm{K}^{+}$analysis, potassium 1, 2 and 3 reagents were used. One sachet of potassium 1 and 3 was separately dissolved in $1 \mathrm{ml}$ of $\mathrm{dH}_{2} \mathrm{O}$ and labelled as P1 and P3. Then, 10 $\mu l$ of P1 was transferred into each MTP well and supplemented with $10 \mu \mathrm{l}$ of potassium 2 reagent. Subsequently, $200 \mu \mathrm{l}$ of the aliquot sample was added to each MTP well and after $30 \mathrm{~s}$ of incubation, $10 \mu \mathrm{l}$ of P3 was added. The solutions were incubated for $3 \mathrm{~min}$ and the absorbance recorded at $655 \mathrm{~nm}$. For $\mathrm{PO}_{4}{ }^{3-}$ analysis, one powder pillow of PhosVer3 was dissolved in $1 \mathrm{ml}$ of $\mathrm{dH}_{2} \mathrm{O}$. Then, $20 \mu \mathrm{l}$ of the dissolved PhosVer 3 and $200 \mu$ of the aliquot sample were mixed thoroughly in each MTP well, incubated for $2 \mathrm{~min}$ and the absorbance measured at $750 \mathrm{~nm}$. For $\mathrm{NH}_{4}^{+}$analysis, one sachet each of ammonia salicylate and ammonia cyanurate was separately dissolved in $1 \mathrm{ml}$ of $\mathrm{dH}_{2} \mathrm{O}$. Ten $\mu \mathrm{l}$ of ammonia salicylate and $200 \mu \mathrm{l}$ of the aliquot sample were transferred to and mixed in each well. After incubating the solutions for $3 \mathrm{~min}, 10 \mu \mathrm{l}$ of ammonia cyanurate was added in each well, incubated for $30 \mathrm{~min}$ and absorbance recorded at $655 \mathrm{~nm}$. All experiments were carried out in triplicate including the negative control (NPKMg only), while blanks (biochar $+\mathrm{dH}_{2} \mathrm{O}$ ) were analysed in duplicate.

\section{PKS Biochar Adsorption on HA}

Adsorption of HA on PKS biochar was investigated using $20 \mathrm{mg}$ litre $^{-1}$ and $50 \mathrm{mg}$ litre $^{-1}$ HA solutions. Aliquots were taken at fixed time interval of 10,20,40, $60 \mathrm{~min}$ and 24, 48, 72 and $96 \mathrm{hr}$, transferred to $1.5-\mathrm{ml}$ Eppendorf tubes containing $5 \mu \mathrm{l}$ of phosphate buffer saline (PBS) solution to ensure the samples were neutral, centrifuged for $5 \mathrm{~min}$ at $4000 \mathrm{rpm}$ (Sigma, Model 3-15) and analysed for the HA absorbance at 410 nm (Daifullah et al., 2004). All experiments were conducted in triplicate including the negative control (HA only) and blank (biochar $+\mathrm{dH}_{2} \mathrm{O}$ ). Langmuir (1916), Freundlich (1906) and Temkin (Kumar et al., 2007) models were used to fit the equilibrium isotherms (Table 2).

\section{NPKMg Adsorption Study on HA-coated PKS Biochar}

PKS biochar with the optimum $\mathrm{Q}_{\mathrm{e}}$ for $\mathrm{NH}_{4}{ }^{+}$and HA, Brunauer-Emmet-Teller (BET) pore volume as well as $\mathrm{H} / \mathrm{C}$ ratio was selected for further NPKMg adsorption studies. First, $0.4 \mathrm{~g}$ of PKS biochar was added to $10 \mathrm{mg}$ litre $^{-1}$ aqueous HA solution ( $\mathrm{pH} 7$ ) and shaken at $170 \mathrm{rpm}$ until the concentration of HA reached equilibrium, in six replicates. Subsequently the HA-coated PKS biochar was washed with $\mathrm{dH}_{2} \mathrm{O}$ and adjusted to $\mathrm{pH}$ 7. Next, $100 \mathrm{ml}$ of NPKMg solution (50 mg litre ${ }^{-1}$ ) was added into each $250-\mathrm{ml}$ 
Erlenmeyer flask containing the HA-coated PKS biochar. The samples were analysed in triplicate as described above. In addition, blank (HA-coated biochar $+\mathrm{dH}_{2} \mathrm{O}$ ) and negative control (NPKMg only) were analysed in triplicate.

\section{Statistical Analysis}

One way analysis of variance (ANOVA) and post hoc Tukey test were performed to determine the significance of adsorption performance of PKS biochar at $95 \%$ confidence level.

\section{RESULTS AND DISCUSSION}

\section{PKS Biochar Characteristics}

The PKS biochars produced at $400^{\circ} \mathrm{C}, 500^{\circ} \mathrm{C}$ and $600^{\circ} \mathrm{C}$ with $1 \mathrm{hr}$ holding time were characterised in terms of proximate analysis, $\mathrm{pH}$, water holding capacity, CEC and BET (Table 3). The results showed an increase in ash content, fixed carbon, BET surface area and $\mathrm{pH}$ with increasing pyrolysis temperature, while CEC decreased. Significant loss of volatile matter and oxygenated functionalities in PKS due to greater biomass decomposition taking place at higher temperature resulted in a richer carbonaceous material and creation of additional micropores. The
$\mathrm{pH}$ increased with the release of more inorganic residues in the ashes. Water holding capacity did not appear to vary noticeably. Similar trends for ash content, fixed carbon, $\mathrm{pH}$ and BET were reported by Lee et al. (2017) and Rafiq et al. (2016) for different feedstocks.

Since the ash content of PKS biochar was relatively high $(15.5 \mathrm{wt} \%)$, the produced biochar was repeatedly washed with $\mathrm{dH}_{2} \mathrm{O}$ until the conductivity of the solution remained constant in order to reduce the amount of minerals leached from the biochar which could potentially interfere with the employed colorimetric ion analysis in this study. Each colorimetric analysis method has its own interference limit so it is recommended to remove any leaching minerals prior to sorption experiments. The amount of leachable minerals from the PKS biochar was estimated from the TDS readings (Table 4) and compared to the total amount of minerals present based on ash content (Table 3 ). It was found that the relative amount leached from PKS biochar decreased with increasing temperature constituting $9.1 \mathrm{wt} \%$ of ash at $400^{\circ} \mathrm{C}$ and $6.2 \mathrm{wt} \%$ at $600^{\circ} \mathrm{C}$, while holding time had no strong effect on ash leaching at $500^{\circ} \mathrm{C}$. At higher temperatures, biomass decomposition rate increases causing more ash leaching from the original PKS feedstock; hence lesser amount is expected to be leached from the PKS biochar during washing. Eom et al. (2011) reported

TABLE 2. TYPE OF ISOTHERMS USED IN THIS STUDY

\begin{tabular}{|c|c|c|c|}
\hline Isotherm & Model & Description & Reference \\
\hline Langmuir & $\mathrm{C}_{\mathrm{e}} / \mathrm{q}_{\mathrm{e}}=1 / \mathrm{K}_{\mathrm{d}} \mathrm{q}_{\mathrm{m}}+\left(1 / \mathrm{q}_{\mathrm{m}}\right) \mathrm{C}_{\mathrm{e}}$ & $\begin{array}{l}C_{e} / q_{e} \text { against } C_{e} \text { plot is used to determine } q_{m} \\
\text { and } K \text { from slope and intercept of straight } \\
\text { line respectively. }\end{array}$ & Langmuir (1916) \\
\hline Freundlich & $\log \mathrm{q}_{\mathrm{e}}=\log \mathrm{K}_{\mathrm{F}}+1 / \mathrm{n}\left(\log \mathrm{C}_{\mathrm{e}}\right)$ & $\begin{array}{l}\mathrm{K}_{\mathrm{F}} \text { and } \mathrm{n} \text { are indicators of relative adsorption } \\
\text { capacity and intensity respectively and their } \\
\text { values can be obtained from the intercept and } \\
\text { the slope of linear plot of } \log \mathrm{q}_{\mathrm{e}} v s . \log \mathrm{C}_{\mathrm{e}} \text {. }\end{array}$ & Freundlich (1906) \\
\hline Temkin & $\mathrm{q}_{\mathrm{e}}=\mathrm{B} \ln \mathrm{A}+\mathrm{B} \ln \mathrm{C}_{\mathrm{e}}$ & $\begin{array}{l}\mathrm{q}_{\mathrm{e}} \text { vs. } \ln \mathrm{C}_{\mathrm{e}} \text { plot can be used to determine } \\
\text { constants } \mathrm{A} \text { and } \mathrm{B} \text {. }\end{array}$ & Kumar et al. (2007) \\
\hline
\end{tabular}

TABLE 3. PROPERTIES OF PALM KERNEL SHELL BIOCHAR PRODUCED AT $400^{\circ} \mathrm{C}-600^{\circ} \mathrm{C}$ AND $1 \mathrm{hr}$ HOLDING TIME

\begin{tabular}{|c|c|c|c|}
\hline Parameter & $400^{\circ} \mathrm{C}$ & $500^{\circ} \mathrm{C}$ & $600^{\circ} \mathrm{C}$ \\
\hline Moisture (wt $\%$ ) & $4.04 \pm 0.01$ & $2.47 \pm 0.01$ & $1.37 \pm 0.02$ \\
\hline Volatile (wt $\%$ ) & $19.7 \pm 0.3$ & $15.1 \pm 0.1$ & $9.02 \pm 0.01$ \\
\hline Ash $(w t \%)$ & $11.6 \pm 0.4$ & $15.36 \pm 0.08$ & $17.7 \pm 0.9$ \\
\hline Fixed C (wt $\%)$ & $64.7 \pm 0.7$ & $67.0 \pm 0.2$ & $72.0 \pm 0.9$ \\
\hline $\mathrm{pH}$ & $9.1 \pm 0.4$ & $10.3 \pm 0.2$ & $11 \pm 2$ \\
\hline $\mathrm{C}$ yield $(\mathrm{wt} \%)$ & $71.1 \pm 0.1$ & $72.3 \pm 0.5$ & $73.1 \pm 0.3$ \\
\hline Water holding capacity $\left(\mathrm{g} \mathrm{H}_{2} \mathrm{O} / 10 \mathrm{~g}\right)$ & $6.07 \pm 0.07$ & $4.6 \pm 0.4$ & $6.11 \pm 0.1$ \\
\hline Cation exchange capacity $\left(\mathrm{mmol} \mathrm{g}^{-1}\right)$ & $2.48 \pm 0.09$ & $5.87 \pm 0.05$ & $1.2 \pm 0.3$ \\
\hline BET surface area $\left(\mathrm{m}^{2} \mathrm{~g}^{-1}\right)$ & $181 \pm 18$ & $204 \pm 3$ & $329 \pm 4$ \\
\hline
\end{tabular}

Note: BET - Brunauer-Emmet-Teller.

Source: Kong et al. (2014). 
a $28 \mathrm{wt} \%$ decrease in ash content for original poplar wood while Jiang et al. (2013) reduced the ash content of rice straw by $33 \mathrm{wt} \%$. Compared to these literature values our findings are $3-5$ times lower suggesting that the carbonisation of biomass reduces the leachability of plant minerals. However, the observed differences may also be attributed to variations amongst biomass feedstock as well as non-standardised demineralisation protocols calling for further research to clarify this uncertainty.

During the initial washing step the presence of an oil layer was observed. We decided to test the PKS biochars for the presence of bio-oil using Soxhlet method (EPA 3540C). The bio-oil content was found to range from 0.28 to $1.73 \mathrm{wt} \%$ and decreased with holding time and temperature (Table 4). The presence of bio-oil may be due to the allothermal operation and slow heating rates of the biochar reactor. In terms of composition, bio-oil is a mixture of water, phenolic compounds, acetic acid and other organic substances (Kim et al., 2010; Sukiran et al., 2016) which may have beneficial (Kadota and Niimi, 2004) or detrimental (Hale et al., 2013) effects on soil biome and plant growth. Further research is therefore required to identify the effect of biochar production technology and process conditions on bio-oil content in biochar, bio-oil composition and bio-availability as well as its effect on soil health and plant growth.

\section{Adsorption Study}

The ions (i.e. $\mathrm{NO}_{3}^{-}, \mathrm{NH}_{4}^{+}, \mathrm{PO}_{4}^{3-}$ and $\mathrm{K}^{+}$) investigated were analysed using established colorimetric methods, appropriate reagents and absorbance measurements at recommended wavelengths (as described in Materials and Methods section). From here the concentration of each ion in the sample was determined accordingly. A decrease in concentration of the respective ion is due to its sorption and modelled accordingly. Similar sorption processes in binary, tertiary or quaternary systems have been studied elsewhere (Swayampakula et al., 2009). The use of negative controls ensures that effects such as precipitation are accounted for and only net sorption are reported in our study. On the other hand, an increase in concentration as noted for $\mathrm{K}^{+}$illustrates that ions are released, thus no sorption takes place.

\section{NPK and HA Adsorption on PKS Biochar}

Equilibrium adsorption experiments with original PKS biochar (without HA-coating) produced at $400^{\circ} \mathrm{C}, 500^{\circ} \mathrm{C}$ and $600^{\circ} \mathrm{C}$ for $1 \mathrm{hr}$ holding time in neutral aqueous solution showed that $\mathrm{NH}_{4}{ }^{+}$ and HA were adsorbed in contrast to $\mathrm{NO}_{3}^{-}$and $\mathrm{PO}_{4}^{3-}$ (Table 5). PKS biochar produced at $400^{\circ} \mathrm{C}$ exhibited the greatest $\mathrm{Q}_{\mathrm{e}}$ for $\mathrm{NH}_{4}{ }^{+}$and $\mathrm{HA}$. The $\mathrm{Q}_{\mathrm{e}}$ of $\mathrm{PKS}$ biochar produced at $500^{\circ} \mathrm{C}$ and different holding times showed that for $\mathrm{NH}_{4}^{+}$and $\mathrm{HA}$ the optimum holding time were at $1 \mathrm{hr}$ (Table 6). The $\mathrm{Q}_{\mathrm{e}}$ of $\mathrm{NH}_{4}{ }^{+}$ and $\mathrm{H} / \mathrm{C}$ ratio was significantly different $(\mathrm{p}<0.05)$ at different pyrolysis temperatures and holding times unlike HA (Tables 5 and 6). The standard deviation for HA sorption study was high thus affecting the statistical analysis. The high standard deviation may be due to the 10-time lower $\mathrm{Q}_{\mathrm{e}}$ as reported elsewhere

TABLE 4. SUMMARY OF PALM KERNEL SHELL BIOCHAR CHARACTERISTICS AT $25^{\circ} \mathrm{C}$ USED FOR ADSORPTION STUDY $(n=2)$

\begin{tabular}{|c|c|c|c|c|c|}
\hline $\begin{array}{l}\text { Temperature } \\
\left({ }^{\circ} \mathrm{C}\right)\end{array}$ & $\begin{array}{l}\text { Holding time } \\
\text { (hr) }\end{array}$ & $\begin{array}{l}\text { Conductivity } \\
\qquad\left(\mu S \mathrm{~cm}^{-1}\right)\end{array}$ & $\begin{array}{c}\text { TDS } \\
\left(\mathrm{mg} \mathrm{litre}^{-1}\right)\end{array}$ & $\mathrm{pH}$ & $\begin{array}{l}\text { Oil content } \\
\text { (wt. } \% \text { ) }\end{array}$ \\
\hline 400 & 1.0 & $321 \pm 24$ & $0.169 \pm 0.013$ & 8.69 & 0.54 \\
\hline 500 & 1.0 & $312 \pm 12$ & $0.164 \pm 0.006$ & 8.60 & 0.65 \\
\hline 600 & 1.0 & $311 \pm 18$ & $0.164 \pm 0.009$ & 8.88 & 0.28 \\
\hline 500 & 0.5 & $251 \pm 26$ & $0.132 \pm 0.014$ & 8.00 & 1.73 \\
\hline 500 & 1.5 & $271 \pm 26$ & $0.143 \pm 0.013$ & 8.65 & 0.33 \\
\hline
\end{tabular}

Note: TDS - total dissolved solid.

TABLE 5. ADSORPTION CAPACITY (Qe) OF $\mathrm{NH}_{4}^{+}$AND HUMIC ACID (HA) OF PALM KERNEL SHELL BIOCHAR PRODUCED AT DIFFERENT PYROLYSIS TEMPERATURES AND $1 \mathrm{hr}$ HOLDING TIME (n = 3) AT $25^{\circ} \mathrm{C}, \mathrm{pH} 7$

\begin{tabular}{|c|c|c|c|c|}
\hline $\begin{array}{c}\text { Temperature } \\
\left({ }^{\circ} \mathrm{C}\right)\end{array}$ & $\begin{array}{c}\mathrm{Q}_{\mathrm{e}}\left(\mathrm{NH}_{4}^{+}\right) \\
\left(\mathrm{mg} \mathrm{g}^{-1}\right)\end{array}$ & $\begin{array}{l}Q_{e}(H A) \\
\left(\mathrm{mg} \mathrm{g}^{-1}\right)\end{array}$ & $\begin{array}{c}\mathrm{H} / \mathrm{C} \\
\text { rmola ratio* }^{*}\end{array}$ & $\begin{array}{l}\text { BET pore volume } \\
\left(\mathrm{cm}^{3} \mathrm{~g}^{-1}\right)^{*}\end{array}$ \\
\hline 400 & $0.522 \pm 0.036^{\mathrm{a}}$ & $0.649 \pm 0.073^{a}$ & 0.54 & $0.166 \pm 0.003^{\mathrm{a}}$ \\
\hline 500 & $0.444 \pm 0.062^{\mathrm{ab}}$ & $0.328 \pm 0.100^{a}$ & 0.46 & $0.212 \pm 0.004^{b}$ \\
\hline 600 & $0.392 \pm 0.042^{\mathrm{b}}$ & $0.563 \pm 0.274^{\mathrm{a}}$ & 0.39 & $0.308 \pm 0.002^{c}$ \\
\hline
\end{tabular}

Note: Means that do not share a letter within the column are significantly different using Tukey Test $(\mathrm{p}<0.05)$. BET - Brunauer-Emmet-Teller.

Source: *Kong et al. (2016). 
(Kasozi et al., 2010) which approaches the lower detection of the photometric method used. In order to improve precision, it is recommended to include more replicates for HA sorption study or develop another method with a lower detection limit.

Potassium concentration in solution increased linearly over time at the rates of $0.004-0.057 \mathrm{mg} \mathrm{kg}^{-1}$ $\mathrm{hr}^{-1}$ (Figure 1), suggesting that the adopted rigorous washing regime was still insufficient for highly mobile ions such as $\mathrm{K}^{+}$. In order to study potassium adsorption onto biochar a standardised international washing protocol should be developed to ensure no leaching of ash minerals after washing occurs which would affect sorption-relevant physico-chemical properties of the biochar particularly functional groups. Currently, although several washing methods have been adopted by different groups of researchers (Table 1), there is no standard method established yet to harmonise biochar washing for sorption studies. It can also be seen in Table 1 that the adsorbent is either not washed, or the washing step has not been reported, or washing is carried out using different approaches prior to adsorption studies.

As pyrolysis temperature increased, $\mathrm{Q}_{\mathrm{e}}$ of $\mathrm{NH}_{4}{ }^{+}$ and $\mathrm{H} / \mathrm{C}$ ratio decreased (Table 5). The decomposition of PKS increased with increasing pyrolysis temperature due to conversion of hemicellulose, cellulose and lignin into bio-oil, syngas and biochar. A decrease in $\mathrm{H} / \mathrm{C}$ ratio reduced the functional groups (hydroxyl and carboxyl) on biochar active sites (Stevenson, 1994; Chun et al., 2004) which appeared more abundantly at lower pyrolysis temperature. As shown in the fourier transform infrared (FTIR) spectra (Figure 2), the phenolic and hydroxyl $\mathrm{O}-\mathrm{H}$ strectching at $3338 \mathrm{~cm}^{-1}$, the aliphatic $\mathrm{C}-\mathrm{H}$ strectching at $2924 \mathrm{~cm}^{-1}$ and the carboxyl $\mathrm{C}=\mathrm{O}$ strectching at $1716 \mathrm{~cm}^{-1}$ for PKS biochar produced at $600^{\circ} \mathrm{C}$ almost dissappeared compared to the original PKS. The loss of negatively charged functional groups on the PKS biochar surface can therefore explain the observed decrease in $\mathrm{Q}_{\mathrm{e}}$ of $\mathrm{NH}_{4}{ }^{+}$(Table 5).

The BET pore volume of PKS biochar was found to increase with pyrolysis temperature $(p<0.05)$ but not for different holding times (Tables 5 and 6). Similar findings were reported by Shaaban et al. (2014) who showed insignificant changes in pore volume of rubber wood sawdust biochar produced at $500^{\circ} \mathrm{C}$ for $1 \mathrm{hr}\left(6.1 \mathrm{~cm}^{3} \mathrm{~g}^{-1}\right)$ and $3 \mathrm{hr}\left(6.4 \mathrm{~cm}^{3} \mathrm{~g}^{-1}\right)$. Others reported that larger pores have a greater tendency to allow larger ionic forms of nutrients to fit and trap onto the PKS biochar active sites (Kasozi

TABLE 6. ADSORPTION CAPACITY $\left(\mathrm{Q}_{\mathrm{e}}\right)$ OF $\mathrm{NH}_{4}^{+}$AND HUMIC ACID (HA) OF PALM KERNEL SHELL BIOCHAR PRODUCED AT $500^{\circ} \mathrm{C}$ AND DIFFERENT HOLDING TIMES $(\mathrm{N}=3)$ AT $25^{\circ} \mathrm{C}, \mathrm{pH} 7$

\begin{tabular}{ccccc}
\hline $\begin{array}{c}\text { Holding time } \\
(\mathbf{h r})\end{array}$ & $\begin{array}{c}\mathrm{Q}_{\mathrm{e}}\left(\mathbf{N H}^{+}\right) \\
\left(\mathbf{m g ~ g}^{-1}\right)\end{array}$ & $\begin{array}{c}\mathbf{Q}_{\mathrm{e}}(\mathbf{H A}) \\
\left(\mathbf{m g ~ g}^{-1}\right)\end{array}$ & $\begin{array}{c}\mathrm{H} / \mathrm{C} \\
\text { molar ratio }^{*}\end{array}$ & $\begin{array}{c}\text { BET pore volume } \\
\left(\mathbf{c m}^{\mathbf{3}} \mathbf{~ g}^{-1}\right)^{*}\end{array}$ \\
\hline 0.5 & $0.26 \pm 0.02 \mathrm{a}$ & $0.09 \pm 0.08 \mathrm{a}$ & 0.52 & $0.241 \pm 0.013 \mathrm{a}$ \\
1 & $0.44 \pm 0.06 \mathrm{~b}$ & $0.33 \pm 0.10 \mathrm{a}$ & 0.46 & $0.212 \pm 0.004 \mathrm{~b}$ \\
1.5 & $0.22 \pm 0.09 \mathrm{~b}$ & $0.36 \pm 0.27 \mathrm{a}$ & 0.32 & $0.285 \pm 0.004 \mathrm{c}$ \\
\hline
\end{tabular}

Note: Means that do not share a letter within the column are significantly different using post hoc Tukey Test $(\mathrm{p}<0.05)$. BET - Brunauer-Emmet-Teller.

Source: *Kong et al. (2016).

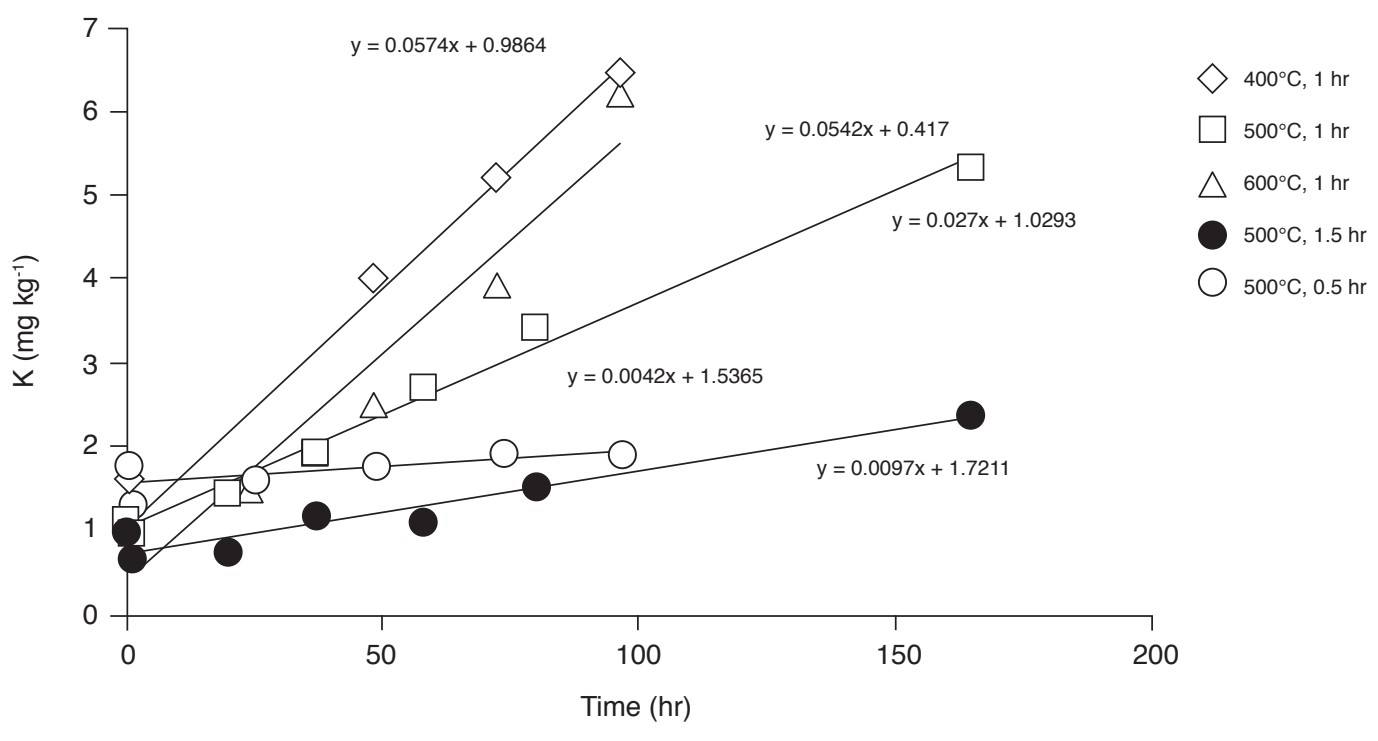

Figure 1. Potassium (K) concentration in various biochar types in NPK solution towards time (n=3) at $25^{\circ} \mathrm{C}, p H 7$. 


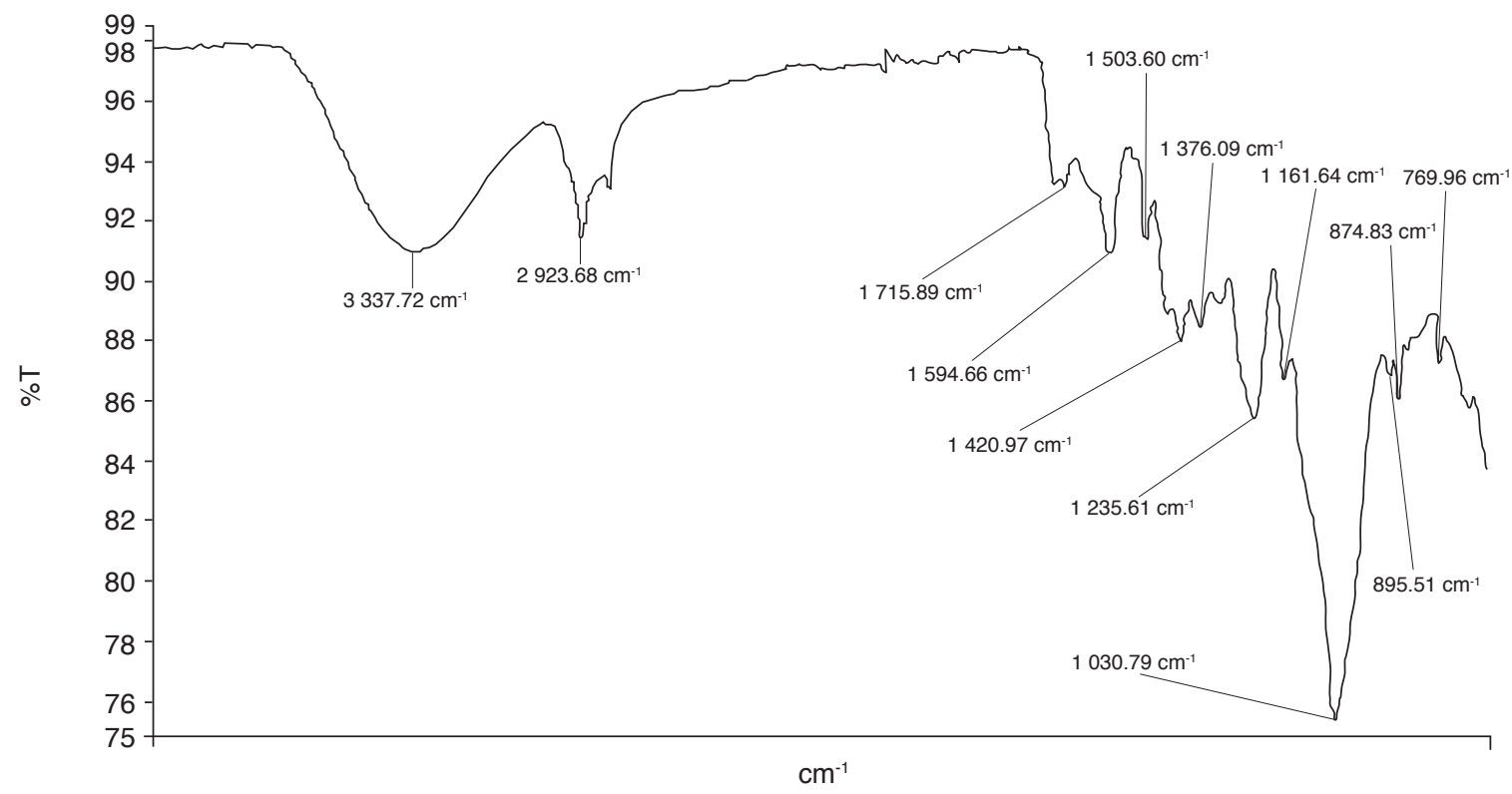

(a) Raw PKS

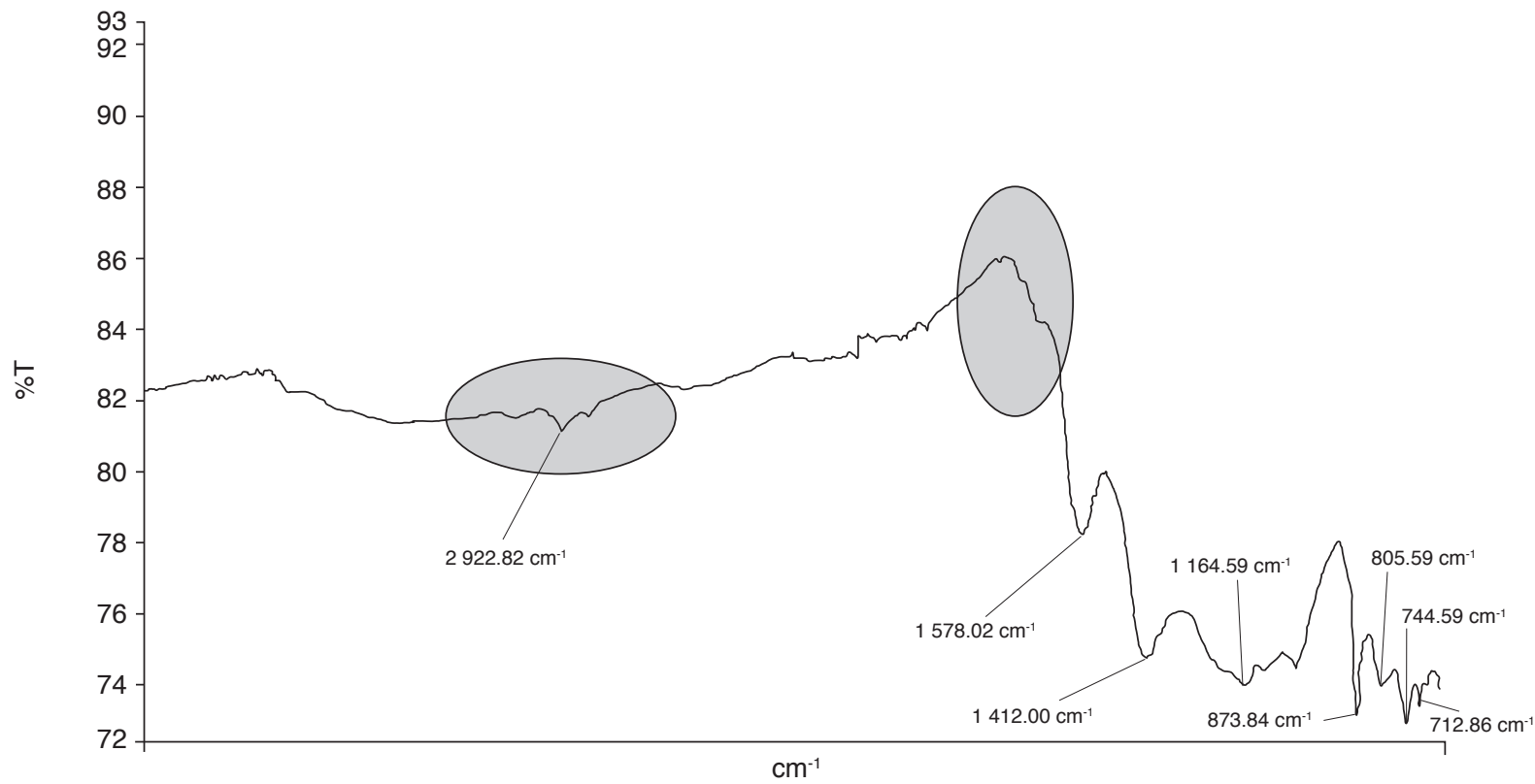

(b) PKS biochar $\left(600^{\circ} \mathrm{C}, 30 \mathrm{~min}\right)$

Note: $\bigcirc$ - Indicates the disappearance of FTIR adsorption bands at around 2900-3500 $\mathrm{cm}^{-1}$ (phenolic, hydroxyl and alkyl functional groups) and $1710-1780 \mathrm{~cm}^{-1}$ (carboxyl functional group).

Figure 2. The Fourier transform infrared (FTIR) spectra of the raw palm kernel shell (PKS) and PKS biochar (temperature: $600^{\circ} \mathrm{C}$ and residence time: $30 \mathrm{~min}$ ).

et al., 2010; Downie et al., 2009) leading to more adsorption. This trend however, was not conclusive in this study most probably due to high variations in $\mathrm{Q}_{\mathrm{e}}$ (Tables 5 and 6).

The $\mathrm{Q}_{\mathrm{e}}$ of HA on PKS biochar ranged between 0.09 to $0.65 \mathrm{mg} \mathrm{g}^{-1}$ (Tables 5 and 6 ), which was 1 to 3 orders of magnitude lower than those reported elsewhere (Cheng et al., 2008; Kasozi et al., 2010).
In studying the $Q_{e}$ of $H A$ using three adsorption isotherm models (Table 2), it was found that the Freundlich isotherm gave the best fit for PKS biochar produced at $600^{\circ} \mathrm{C}$ and $1 \mathrm{hr}$ holding time with $\mathrm{R}^{2}$ of 0.905 (Table 7). The other two models showed lower $\mathrm{R}^{2}$ of 0.881 (Temkin) and 0.828 (Langmuir), respectively. This was in agreement with Kasozi et al. (2010) who investigated the $Q_{e}$ of catechol 
and HA for biochars produced from pine, oak and grass at different temperatures. In other cases using activated carbon as adsorbent for HA, the best fit for HA was either Langmuir (Godini et al., 2011), Freundlich (Kasozi et al., 2010) or both (Daifullah et al., 2004; Zhu et al., 2010; Godini et al., 2011).

\section{NPK Adsorption on HA-coated PKS Biochar}

The PKS biochar pyrolysed at $600^{\circ} \mathrm{C}$ and $1 \mathrm{hr}$ was selected for further NPK adsorption studies based on $\mathrm{Q}_{\mathrm{e}}$ for $\mathrm{NH}_{4}{ }^{+}$and HA, BET pore volume and $\mathrm{H} / \mathrm{C}$ ratio. The $\mathrm{NH}_{4}{ }^{+}$sorption experiments with HA-coated PKS biochar $\left(600^{\circ} \mathrm{C}, 1 \mathrm{hr}\right)$ demonstrated a $55.9 \%$ reduction in $\mathrm{Q}_{\mathrm{e}}$ for $\mathrm{NH}_{4}{ }^{+}$compared with uncoated biochar (Table 8). The finding followed a similar trend as reported by Chen and $\mathrm{Wu}$ (2004) who found that when the concentration of HA in biochar was less than the HA critical concentration (0.4 mg litre $\left.{ }^{-1}\right)$, the adsorption of $\mathrm{Cu}^{2+}$ decreased as the HA concentration increased and vice versa. Similar reduction was also observed by Martin et al. (2012) who found that the $Q_{e}$ of herbicides diuron and artrazine on aged biochar was reduced by $47 \%$ and $68 \%$, respectively. The observed drop in $Q_{e}$ of $\mathrm{NH}_{4}^{+}$may be due to a decrease in the specific surface area caused by HA-coating (Chen and Wu, 2004). However, more research is required to elucidate this phenomenon.

The release of $\mathrm{K}^{+}$into the solution and adsorption of $\mathrm{NH}_{4}^{+}$demonstrated that addition of PKS biochar into soil increases $\mathrm{K}$ content while decreasing the $\mathrm{N}$ content in soil, thus indicating temporal $\mathrm{N}$ immobilisation (Tammeorg et al., 2014; Nelson et al., 2011; Bruun et al., 2012; Lehmann et al., 2003; Asai et al., 2009) causing $\mathrm{N}$ deficiency in plants growing in biochar-amended soil. As a result,

TABLE 7. SUMMARY OF LANGMUIR, FREUNDLICH AND TEMKIN ISOTHERMS FOR HUMIC ACID ADSORPTION ON PALM KERNEL SHELL BIOCHAR $\left(600^{\circ} \mathrm{C}, 1 \mathrm{hr}\right)(\mathrm{n}=3)$ AT $25^{\circ} \mathrm{C}, \mathrm{pH} 7$

\begin{tabular}{lll}
\hline Langmuir & Freundlich & Temkin \\
\hline $\mathrm{R}^{2}=0.828$ & $\mathrm{R}^{2}=0.905$ & $\mathrm{R}^{2}=0.881$ \\
$\mathrm{Q}_{\mathrm{m}}=1.15$ & $\mathrm{~K}_{\mathrm{f}}=10.97$ & $\mathrm{~B}=0.243$ \\
$\mathrm{~K}_{\mathrm{d}}=0.132$ & $\mathrm{n}=0.532$ & $\mathrm{~A}=3$ \\
\hline
\end{tabular}

TABLE 8. $\mathrm{NH}_{4}{ }^{+}$ADSORPTION CAPACITY $\left(Q_{\mathrm{e}}\right)$ ON ORIGINAL AND HUMIC ACID (HA) COATED PALM KERNEL SHELL (PKS) BIOCHAR (n=3) AT $25^{\circ} \mathrm{C}, \mathrm{pH} 7$

\begin{tabular}{lcc}
\hline Biochar & $\begin{array}{c}\mathrm{Q}_{\mathrm{e}} \text {, biochar } \\
\text { uncoated } \\
\left(\mathbf{m g ~ g}^{-1}\right)\end{array}$ & $\begin{array}{c}\mathrm{Q}_{\mathrm{e}} \text {, biochar } \\
\text { HA-coated } \\
\left(\mathbf{m g ~ g}^{-1}\right)\end{array}$ \\
\hline $\begin{array}{l}\mathrm{PKS} \text { biochar } \\
600^{\circ} \mathrm{C} \text { at } 1 \mathrm{hr}\end{array}$ & $0.39 \pm 0.04$ & $0.17 \pm 0.02$ \\
\hline
\end{tabular}

the intended crop growth dynamics and yield may be affected in the first cropping season as reported by Major et al. (2010). In order to overcome these observed initial negative effects, biochar should be added to compost or anaerobic digesters to charge them with accessible nutrients prior to addition to soil (Manickam et al., 2012; 2016; Mumme et al., 2014).

\section{CONCLUSION}

Pyrolysing PKS in an allothermal reactor, the PKS biochar sorption-relevant properties e.g. CEC decreased while ash content, fixed carbon, BET surface area and $\mathrm{pH}$ increased with increasing pyrolysis temperature and holding time. Waterwashed PKS biochar was able to adsorb $\mathrm{NH}_{4}^{+}$ and $\mathrm{HA}$ but not $\mathrm{NO}_{3}^{-}, \mathrm{PO}_{4}^{3-}$ and $\mathrm{K}^{+}$in quaternary aqueous solutions. The HA-coated PKS biochar had a lower capacity to adsorb $\mathrm{NH}_{4}{ }^{+}$demonstrating the difficulty in extrapolating experimental findings of classical biochar sorption studies to actual biocharnutrient interactions in a soil environment. It is essential to investigate the safe application of the produced PKS biochar containing bio-oil. Further work is needed to explore and understand the shortand long-term roles and interactions of the biochar with HA, soil constituents, microorganism, fertiliser and plants. A standardised international method is required to streamline washing protocol currently used to prepare carbonised adsorbents for sorption studies.

\section{ACKNOWLEDGEMENT}

The authors wish to thank MPOB for providing the Graduate Student Assistantship Scheme (GSAS) to Arasu Uttran to conduct this research work for a Master's degree at Universiti Kuala Lumpur (UniKL), Melaka, Malaysia.

\section{REFERENCES}

AHMAD, O H; ROSLIZA, S; MAJID, N M A and JALLOH, M B (2012). Effect of N, P and K humates on dry matter of Zea mays and soil $\mathrm{pH}$, exchangeable ammonium and available nitrate. African J. Biotechnology, 11: 9566-9571.

ASAI, H; SAMSON, B K; STEPHAN, H M; SONGYIKHANGSUTHOR, K; HOMMA, K; KIYONO, Y and HORIE, T (2009). Biochar amendment techniques for upland rice production in Northern Laos 1. Soil physical properties, leaf SPAD and grain yield. Field Crops Research, 111: 81-84. 
BERNARD, R; AHMED, $\mathrm{O} \mathrm{H}$ and AB MAJID, N M (2011). Utilization of activated carbon produced from Sago hampas (Metroxylon sagu) to reduce ammonia loss from urea. Intl. J. Physical Sci., 6:61406146.

BRUUN, E W; AMBUS, P; EGSGAARD, $\mathrm{H}$ and HAUGGAARD-NIELSEN, H (2012). Effects of slow and fast pyrolysis biochar on soil $\mathrm{C}$ and $\mathrm{N}$ turnover dynamics. Soil Biol Biochem., 46: 73-79.

CHEN, J P and WU, S (2004). Simultaneous adsorption of copper ions and humic acid onto an activated carbon. J. Colloid and Interface Sci., 280: 334342.

CHENG, C H; LEHMANN, J and ENGELHARD, M $H$ (2008). Natural oxidation of black carbon in soils: Change in molecular form and surface charge along a climosequence. Geochim Cosmochim Acta, 72: 15981610 .

CHUN, Y; SHENG, G; CHIOU, C T and XING, B (2004). Compositions and sorptive properties of crop residue-derived chars. Environ. Sci. Technol., 38(17): 4649-4655.

DAY, B A and NIGHTINGALE, H I (1984). Relationship between ground-water silica, total dissolved solids, and specific electrical conductivity. Ground Water, 22(1): 80-85.

DAIFULLAH, A A M; GIRGIS, B S and GAD, H M H (2004). A study of the factors affecting the removal of humic acid by activated carbon prepared from biomass material. Colloids and Surfaces A: Physicochem. Eng. Aspects, 235: 1-10.

DOWNIE, A; CROSKY, A and MUNROE, P (2009). Physical properties of biochar. Biochar for Environmental Management (Lehmann, J and Joseph, S eds.). London, Earthscan. p. 13-32.

DUGAN, E; VERHOEF, A; ROBINSON, $S$ and SOHI, S (2010). Biochar from sawdust, maize stover and charcoal: Impact on water holding capacities of three soils from Ghana. Paper presented at the $19^{\text {th }}$ World Congress of Soil Science; Soil Solutions for a Changing World. Brisbane, Australia. 1 - 6 August 2010 .

EOM, I Y; KIM, K H; KIM, J Y; LEE, S M; YEO, H M; CHOI, I G and CHOI, J W (2011). Characterization of primary thermal degradation features of lignocellulosic biomass after removal of inorganic metals by diverse solvents. Bioresource Technology, 102: 3437-3444.

FREUNDLICH, H M F (1906). Over the adsorption in solution. J. Phys. Chem., 57: 385-470.
GAI, X; WANG, H; LIU, J; ZHAI, L; LIU, S; REN, T and LIU, H (2014). Effects of feedstock and pyrolysis temperature on biochar adsorption of ammonium and nitrate. PLOS ONE 9: e113888.

GODINI, H; KHORRAMABADY, $G S$ and MIRHOSSEINI, S H (2011). The application of ironcoated activated carbon in humic acid removal from water. Paper presented at the $2^{\text {nd }}$ International Conference on Environmental Sci. and Tech. Singapore. 26-28 February 2011.

GUO, Y and ROCKSTRAW, D (2007). Activated carbon prepared from rice hull by one-step phosphoric acid activation. Microporous Mesoporous Matter, 100: 12-19.

HALE, S E; ALLING, V; MARTINSEN, V; MULDER, J; BREEDVELD, G D and CORNELISSEN, G (2013). The sorption and desorption of phosphate-P, ammonium- $\mathrm{N}$ and nitrate- $\mathrm{N}$ in cacao shell and corn cob biochars. Chemosphere, 91: 1612-1619.

HARYATI, Z; LOH, S K; KONG, S-H and BACHMANN, R T (2018). Pilot scale biochar production from palm kernel shell (PKS) in a fixed bed allothermal reactor. J. Oil Palm Res. Vol.30(3): 472-484.

HOLLISTER, C C; BISOGNI, J J and LEHMANN, J (2013). Ammonium, nitrate, and phosphate sorption to and solute leaching from biochars prepared from corn stover (L.) and oak wood (spp.). J. Environmental Quality, 42: 137-144.

JIANG, L; HU, S; SUN, L S; SU, S; XU, K; HE, L $M$ and XIANG, J (2013). Influence of different demineralization treatments on physicochemical structure and thermal degradation of biomass. Bioresource Technology, 146: 254-260.

KADOTA, M and NIIMI, Y (2004). Effects of charcoal with pyroligneous acid and barnyard manure on bedding plants. Scientia Horticulturae, 101: 327-332.

KASIM, S; AHMAD, O H; MAJID, N M A; YUSOP, M $\mathrm{K}$ and JALLOH, M B (2009). Reduction of ammonia loss by mixing urea with liquid humic acids isolated from tropical peat soil. American J. Agricultural and Biological Sci., 4: 18-23.

KASOZI, G N; ZIMMERMAN, A R; NKEDI-KIZZA, $P$ and GAO, B (2010). Catechol and humic acid sorption onto a range of laboratory-produced black carbons (biochars). Environ. Sci. Technol., 44: 61896195.

KIM, S J; JUNG, S H and KIM, J S (2010). Fast pyrolysis of palm kernel shells: Influence of operation parameters on the bio-oil yield and the 
yield of phenol and phenolic compounds. Bioresource Technology, 101: 9294-9300.

KLOSS, S; ZEHETNER, F; DELLANTONIO, A; HAMID, R; OTTNER, F; LIEDTKE, V; SCHWANNINGER, $\mathrm{M}$; GERZABEK, $\mathrm{M} \mathrm{H}$ and SOJA, G (2012). Characterization of slow pyrolysis biochars: effects of feedstocks and pyrolysis temperature on biochar properties. J. Environ. Qual., 41: 990-1000.

KONG, S H (2016). Production and Characterization of Palm Kernel Shell Biochar via Biochar Experimenter's Kit (BEK). Master thesis. Universiti Kebangsaan Malaysia.

KONG, S H; LOH, S K; BACHMANN, R T; CHOO, Y M; SALIMON, J and ABDUL RAHIM, S (2014). Production and physico-chemical characterization of biochar from palm kernel shell. AIP Conf. Proc. 1571: 749. http:/ / dx.doi.org/10.1063/1.4858744.

KRULL, E S; BALDOCK, J A; SKJEMSAD, J $O$ and SMEMIK, R J (2009). Characteristics of biochar: organo-chemical properties. Biochar for Environmental Management (Lehmann, J and Joseph, S eds.). London, Earthscan. p. 53-65.

KUMAR, $\mathrm{M}$ S; BINUPRIYA, A R; VIJAVARAGHAVAN, K and YUN, S I (2007). Two and three-parameter isothermal modeling for liquid-phase sorption of procion blue $\mathrm{HB}$ by inactive mycelial biomass of panus fulvus. J. Chem. Technol. Biotechnol, 82: 389-398.

LANGMUIR, I (1916). The constitution and fundamental properties of solids and liquids. J. Am. Chem. Soc., 38: 2221-2295.

LEE, C L; H`NG, P S; PARIDAH, T; CHIN, K L; KHOO P S; RAJA NAZRIN, R A; ASYIKIN, S N and MAMINSKI, M (2017). Effect of reaction time and temperature on the properties of carbon black made from palm kernel and coconut shell. Asian J. Scientific Research, 10: 24-33.

LEHMANN, J; DA SILVA JR, J P; STEINER, C; NEHLS, T; ZECH, W and GLASER, B (2003). Nutrient availability and leaching in an archaeological anhrosol and ferralsol of the central Amazon basin: fertilizer, manure and charcoal amendments. Plant Soil, 249: 343-357.

LEHMANN, J; GAUNT, J and RONDON, M (2006). Biochar sequestration in terrestrial ecosystem - A review. Mitigation and Adaptation Strategies for Global Change, 11: 403-427.

LIANG, B; LEHMANN, J; SOLOMAN, D; KINYANGI, J; GROSSMAN, J; O'NEILL, B;
SKJEMSTAD, J O; THIES, J; LUIZAO, F J; PETERSON, J and NEVES, E G (2006). Black carbon increases cation exchange capacity in soils. Soil. Sci. Soc. Am. J., 70: 1719-1730.

MAJOR, J; RONDON, M; MOLINA, D; RIHA, S J and LEHMANN, J (2010). Maize yield and nutrition during 4 years after biochar application to a Colombian savanna oxisol. Plant Soil, 333: 117-128.

MANICKAM, T; BACHMANN, R T; ILLANI, Z; ZULKEFLI, M; HUSNI, M and SAMSURI, A (2012). Characterization of local mill rice husk charcoal and its effect on compost properties. Malaysian J. Soil Science, 16: 89-102.

MANICKAM, T; BACHMANN, R T; IBRAHIM, I Z; ANIF, A H M and WAHID, S A (2016). Nutrient retention capacity of rice husk biocharcoal in cocomposted poultry manure. J. Tropical Agriculture and Food Science, 44: 197-209.

MARTIN, S M; KOOKANA, R S; ZWIETEN, L V and KRULL, E (2012). Marked changes in herbicide sorption-desorption upon ageing of biochars in soil. J. Hazardous Materials, 231-232: 70-78.

MIZUTA, K; MASTSUMOTO, T; HATATE, Y; NISHIHARA, $K$ and NAKANISHI, $T$ (2004). Removal of nitrate-nitrogen from drinking water using bamboo powder charcoal. Bioresource Technology, 95: 255-257.

MUMME, J; SROCKE, F; HEEG, K and WERNER, M (2014). Use of biochars in anaerobic digestion. Bioresource Technology, 164: 189-197.

NELSON, N O; AGUDELO, S C; YUAN, W Q and GAN, J (2011). Nitrogen and phosphorus availability in biochar-amended soils. Soil Sci, 176: 218-226.

RAFIQ, $\mathrm{M}$ K; BACHMANN, $\mathrm{R} \mathrm{T}$; RAFIQ, M T; SHANG, Z; JOSEPH, $S$ and LONG, R (2016). Influence of pyrolysis temperature on physicochemical properties of corn stover (Zea mays L.) biochar and feasibility for carbon capture and energy balance. PLOS ONE, 11: e0156894.

SHAABAN, A; SE, S M; DIMIN M F; JUOI, J M; MOHD HUSIN, M F and MITAN, N M N (2014). Influence of heating temperature and holding time on biochars derived from rubber wood sawdust via slow pyrolysis. J. Analytical and Applied Pyrolysis, 107: 31-39.

SOMBROEK, W; RUIVO, M L; FEARNSIDE, P M; GLASER, B and LEHMANN, J (2003). Amazonian dark earths as carbon stores and sinks. Amazonian Dark Earths: Origin, Properties, Management 
(Lehmann, J; Kern, D C; Glaster, B and Woods, W I eds.). Dordrecht, Netherland, Kluwer Academic Publishers. p. 473-486.

SPOKAS, K A (2010). Review of the stability of biochar in soils: predictability of $\mathrm{O}: \mathrm{C}$ molar ratios. Carbon Management, 1(2): 289-303. DOI: $10.4155 /$ cmt.10.32.

SPOKAS, K A; NOVAK, J M and VENTEREA, R T (2011). Biochar's role as an alternative N-fertilizer: ammonia capture. Plant and Soil, 350: 35-42.

STEINER, C; GLASER, B; TEIXEIRA, W G; LEHMANN, J; BLUM, W E H and ZECH, W (2008). Nitrogen retention and plant uptake on a highly weathered central Amazonian ferralsol amended with compost and charcoal. J. Plant Nutrition Soil Sci., 171: 893-899.

STEVENSON, F J (1994). Humus Chemistry: Genesis, Composition, Reactions. Second edition. Wiley.

SUKIRAN, M A; LOH, S K and ABU BAKAR, N (2016). Production of bio-oil from fast pyrolysis of oil palm biomass using fluidised bed reactor. $J$. Energy Technologies and Policy, 6(9): 52-62.

SWAYAMPAKULA, K; BODDU, V M; NADAVALA, $S \mathrm{~K}$ and ABBURI, K (2009). Competitive adsorption of $\mathrm{Cu}$ (II), Co (II) and Ni (II) from their binary and tertiary aqueous solutions using chitosancoated perlite beads as biosorbent. J. Hazard Mater., 170(2-3): 680-689.

TAMMEORG, P; SIMOJOKI, A; MÄKELÄ, P; STODDARD, F L; ALAKUKKU, L and HELENIUS, J (2014). Biochar applications to a fertile sandy clay loam in boreal conditions: effect on soil properties and yield formation of wheat, turnip rape and faba bean. Plant Soil, 374(1-2): 89-107.

TAUFIK, M Y M; AHMED, O H and MUHAMAD, A M N (2011). Ammonia loss reduction, exchangeable ammonium and available nitrate retention in soil treated with urea mixed with HA and acid sulphate soil. Int. J. Physical Sci., 6: 4897-4902.

TOPOLIANTZ, S; PONGE, J F and BALLOF, S (2005). Maniac peel and charcoal: A potential organic amendment for sustainable soil fertility in the tropics. Biol. Fert. Soils, 41: 15-21.

VIJAYA, S; MA, A N; CHOO, Y M and NIK MERIAM, N S (2008). Life cycle inventory of the production of crude palm oil - A gate to gate case study of 12 palm oil mills. J. Oil Palm Res. Vol. 20: 484-494.

WANG, B; LEHMANN, J; HANLEY, K; HESTRIN, R and ENDERS, A (2015a). Adsorption and desorption of ammonium by maple wood biochar as a function of oxidation and $\mathrm{pH}$. Chemosphere, 138: 120-126.

WANG, Z; GUO, H; SHEN, F; YANG, G; ZHANG, Y; ZENG, Y and DENG, S (2015b). Biochar produced from oak sawdust by Lanthanum (La)involved pyrolysis for adsorption of ammonium $[\mathrm{NH} 4(+)]$, nitrate [NO3(-)], and phosphate [PO4(3-)]. Chemosphere, 119: 646-653.

WOOLF, D; AMONETTE, J E; STREET-PERROTT, F A; LEHMANN, J and JOSEPH, S (2010). Sustainable biochar to mitigate global climate change. Nature Communications, 1(56): 1-9.

YAO, Y; GAO, B; ZHANG, M; INYANG, $\mathrm{M}$ and ZIMMERMAN, A R (2012). Effect of biochar amendment on sorption and leaching of nitrate, ammonium, and phosphate in a sandy soil. Chemosphere, 89: 1467-1471.

ZHU, Z; HUANG, K and ZHOU, Y (2010). Adsorption behaviours of HA absorbing by activated carbon from natural water. Paper presented at the $2^{\text {nd }}$ Conference on Env. Sci. and Information Application Tech. Wuhan, China. 17-18 July 2010. 